\title{
Emotional Intelligence - A Factor Influencing the Nature of Locus of Control of Student Teachers - An Analytical Study
}

\author{
C. Ashok $\operatorname{Kumar}^{1} *$
}

Keywords: Emotional Intelligence, Influencing, Locus Of Control, Student, Teachers

Teaching is a complex job and it requires more specific knowledge, attitude and skills and behaviour patterns, which can be acquired only through training. During the training period, many pleasant experiences are provided to the student teachers. With the help of these experiences, they can develop favorable attitude towards themselves, their job and their students. Teaching comprises many major and minor skills. These skills are to be identified and developed in the student teachers through systematic programming of teacher training.

\section{Emotional Intelligence}

Robert A. Baron (2003) defines emotional intelligence as, "a cluster of traits or abilities relating to the emotional side of life - abilities such as recognizing and managing one's own emotions, being able to motivate oneself and restrain one's impulses, recognizing and managing other's emotions, and handling interpersonal relationship in an effective manner”.

Hence emotional intelligence may be stated as the capacity to reason with emotion in four areas: to perceive emotion, to integrate it in thought, to understand it and to manage it. According to this statement, every one of us may be found to have varying capacities and abilities with regard to one's dealings with emotions.

\section{Goleman (1995) suggests that emotional intelligence consists of five major parts:}

- Knowing our own emotions (Self - awareness)

- Managing our emotions (Self - regulation)

- Motivating ourselves (Motivation)

- Recognizing the emotions of others (Empathy) and

- Handling relationships (Social skills).

\footnotetext{
${ }^{1}$ Assistant Professor in Biological Science, Oxford College of Education, West Pirattiyur, Tiruchirappalli, Tamilnadu, India

*Responding Author

(C) 2016 I A Kumar; licensee IJIP. This is an Open Access Research distributed under the terms of the Creative Commons Attribution License (http://creativecommons.org/licenses/by/2.0), which permits unrestricted use, distribution, and reproduction in any Medium, provided the original work is properly cited.
} 


\section{Emotional Intelligence - A Factor Influencing the Nature of Locus of Control of Student Teachers - An Analytical Study}

In working situation, emotional intelligence helps more than one's intellectual potential or even professional skills and competencies. A professionally competent person having poor emotional intelligence may suffer on account of his inability to deal with his self or getting along properly with others. For handling mental relationships, emotional intelligence is very much needed.

\section{Locus of Control}

Locus of control, according to Rotter's approach, can be divided into two separate sources of control: Internal and External. People with an internal locus of control believe that they control their own destiny. They also believe that their own experiences are controlled by their own skill or efforts. An example would be "The more I study, the better grades I get” (Gershaw, 1989). On the other hand, people who tend to have an external locus of control tend to attribute their experiences to fate, chance, or luck. Examples for external locus of control: if a student attributes either their successes or failures to having a bad day, unfair grading procedures on their teacher's part, or even God's will they can be said to have an external locus of control.

Locus of control refers to the extent to which individuals believe that they can control events that affect them. Individuals with a high internal locus of control believe that events result primarily from their own behaviour and actions. Those with a high external locus of control believe that powerful others, fate, or chance primarily determine events. Those with a high internal locus of control have better control of their behaviour and tend to exhibit more political behaviors than externals and are more likely to attempt to influence other people; they are most likely to assume that their efforts will be successful. They are more active in seeking information and knowledge concerning their situations than do externals.

\section{NEED FOR THE STUDY}

The intention of offering B.Ed. degree course is to instill good teacher behaviour in student teachers. The manifestation of ideal teacher behaviour largely depends on one's ability to make right decisions at the right moment. The value system formed by the individuals, the mental ability and the socio - emotional maturity may be playing a significant role in manifesting a desired social behaviour. The student teachers who are to be role models to the younger generation need to be persons of good mental health with essential values and virtues for demonstrating good emotional and social skills. All these characteristics are imbedded in the criterion emotional intelligence. Moreover the ability to control ones' behaviour is attributed to his / her locus of control.

Therefore an inherent relationship is obvious between emotional intelligence and locus of control. As these two psychological characteristics are required for these student teachers to be resourceful in the teaching profession, an intensive study of these two characteristics is of very importance. Moreover the impact of emotional intelligence on locus of control will yield 


\section{Emotional Intelligence - A Factor Influencing the Nature of Locus of Control of Student Teachers -}

An Analytical Study

information needed for preparing useful programs of teaching to inculcate in them the essential psycho-socio characteristics. Hence the present study is stated as given below.

\section{Statement of the Problem}

"Emotional Intelligence - A Factor Influencing the Nature of Locus of Control of Student Teachers - An Analytical Study"

\section{OPERATIONAL DEFINITIONS}

\section{Locus of Control:}

Locus of control refers to the extent to which individuals believe that they can control events that affect them. Individuals with a high internal locus of control believe that events result primarily from their own behaviour and actions.

\section{Emotional Intelligence:}

Emotional intelligence as, "a cluster of traits or abilities relating to the emotional side of life abilities such as recognizing and managing one's own emotions, and managing other's emotions, and handling interpersonal relationship.

\section{Students of Colleges of Education:}

By this the investigator means students doing B.Ed., course in Colleges of Education in Chennai.

\section{Analytical Study:}

By this the investigator means the task of investigating the nature of Dependent and Independent variables in terms of the total sample as well as in respect of the sub - samples formed of the background variables.

\section{OBJECTIVES}

1. To find out the level of Emotional Intelligence of Student Teachers in the Colleges of Education in Chennai.

2. To identify the type of Locus of Control possessed by Student Teachers in the Colleges of Education in Chennai.

3. To find the level of Emotional Intelligence of Student Teachers having Internal and External Locus of Control.

4. To find out the significance of differences in the Emotional Intelligence of Student Teachers having Internal and External Locus of Control.

5. To find the level of Emotional Intelligence of Student Teachers having Internal and External Locus of Control in terms of Birth Order and Optional Subjects.

6. To find the significance of difference in Emotional Intelligence of Student Teachers having Internal and External Locus of Control in terms of Birth Order and Optional Subjects. 


\section{Hypothesis}

1. There is no significance of differences in the Emotional Intelligence of Student Teachers having Internal and External Locus of Control.

2. There is no significance of difference in Emotional Intelligence of Student Teachers having Internal and External Locus of Control in terms of Birth Order and Optional Subjects.

\section{Population and Sample}

All the students doing B.Ed. degree course in Colleges of Education in Chennai form the population of the present study.

Form the population, the investigator has taken 821 student teachers through random sampling technique.

\section{Research Instruments}

1. Locus of Control Scale developed by Julian Rotter (1966).

2. Emotional Intelligence Inventory developed by Anukool Hyde et al., (2001).

\section{ANALYSIS OF DATA}

H1: The level of Emotional Intelligence of Student Teachers in Chennai Districts.

Table 1, The table shows that the Emotional intelligence of student teachers studying in Colleges of Education.

\begin{tabular}{|l|l|l|l|l|l|l|}
\hline \multirow{2}{*}{ Variable } & \multicolumn{2}{|l|}{ Low } & \multicolumn{2}{l|}{ Average } & \multicolumn{2}{l|}{ High } \\
\cline { 2 - 8 } & $\mathrm{N}$ & $\%$ & $\mathrm{~N}$ & $\%$ & $\mathrm{~N}$ & $\%$ \\
\hline Emotional Intelligence & 74 & 9.01 & 65 & 7.92 & 682 & $83.07^{*}$ \\
\hline
\end{tabular}

*indicates the level Emotional Intelligence

\section{Inference}

The above table inferred that the emotional intelligence of student teachers studying in Chennai districts is high.

$\mathrm{H}_{2}$ : The type of Locus of Control possessed by Student Teachers in the Colleges of Education in Chennai.

Table 2, The table shows that the type of Locus of Control of Student Teachers Studying in colleges of Education.

\begin{tabular}{|l|l|l|l|l|}
\hline \multirow{2}{*}{ Variable } & \multicolumn{2}{|l|}{ Internal } & \multicolumn{2}{l|}{ External } \\
\cline { 2 - 5 } & $\mathrm{N}$ & $\%$ & $\mathrm{~N}$ & $\%$ \\
\hline Locus of Control & 174 & 21.19 & 647 & $78.81^{*}$ \\
\hline
\end{tabular}

*indicates the level of locus of control 


\section{Emotional Intelligence - A Factor Influencing the Nature of Locus of Control of Student Teachers -}

\section{An Analytical Study}

\section{Inference}

The above table inferred that the locus of control of student teachers studying in Chennai districts is External locus of control.

$\mathrm{H}_{3}$ : The level of Emotional Intelligence of Student Teachers having Internal and External Locus of Control.

Table 3, The table shows that the Level of Emotional Intelligence of Student Teachers of Internal and External Locus of Control.

\begin{tabular}{|l|l|l|l|l|l|l|}
\hline \multirow{2}{*}{ Locus of Control } & \multicolumn{3}{|l|}{ Low } & \multicolumn{2}{l|}{ Average } & High \\
\cline { 2 - 8 } & $\mathrm{N}$ & $\%$ & $\mathrm{~N}$ & $\%$ & $\mathrm{~N}$ & $\%$ \\
\hline Internal & 43 & 24.71 & 32 & 18.39 & 99 & $56.90^{*}$ \\
\hline External & 31 & 4.79 & 33 & 5.10 & 583 & $90.11^{*}$ \\
\hline
\end{tabular}

*indicates the level Emotional Intelligence

\section{Inference}

The above table inferred that the emotional intelligence of student teachers of locus of control is externally high.

$\mathrm{H}_{4}$ : There is no significant difference in emotional intelligence between the student teachers of internal and external locus of control.

Table 4, The table shows that the difference between Student Teachers of Internal and External Locus of Control and Emotional Intelligence.

\begin{tabular}{|l|l|l|l|l|l|l|}
\hline Locus of Control & $\mathbf{N}$ & Mean & SD & $\begin{array}{l}\text { Calculated 't' } \\
\text { Value }\end{array}$ & $\begin{array}{l}\text { Table } \\
\text { Value }\end{array}$ & Remark \\
\cline { 1 - 4 } & 174 & 86.60 & 33.17 & 15.20 & 1.96 & $\mathrm{~S}$ \\
\hline External & 647 & 128.60 & 29.11 & & \\
\hline
\end{tabular}

$$
\text { S= Significant at } 5 \% \text { level }
$$

\section{Inference}

The above table inferred that the calculated ' $t$ ' value (15.20) is higher than the table value. It indicates that there is a significant difference between emotional intelligence and locus of control (internal and external) of student teachers studying in Chennai districts. 
$H_{5}$ : The level of emotional intelligence of student teachers of internal and external locus of control in terms of birth order and optional subjects.

Table 5, The table shows that the level of Emotional Intelligence of Student Teachers of Internal and External Locus of Control in terms of Birth Order and Optional Subjects

\begin{tabular}{|c|c|c|c|c|c|c|c|c|}
\hline \multirow{8}{*}{ 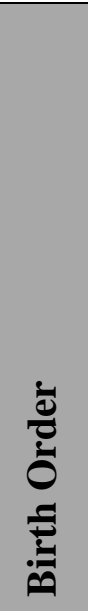 } & \multirow{2}{*}{ Category } & \multirow{2}{*}{$\begin{array}{l}\text { Locus of } \\
\text { Control }\end{array}$} & \multicolumn{2}{|c|}{ Low } & \multicolumn{2}{|c|}{ Average } & \multicolumn{2}{|c|}{ High } \\
\hline & & & $\mathbf{N}$ & $\%$ & $\mathbf{N}$ & $\%$ & $\mathbf{N}$ & $\%$ \\
\hline & \multirow{2}{*}{ First } & Internal & 15 & 21.74 & 15 & 21.74 & 39 & $56.52 *$ \\
\hline & & External & 7 & 3.10 & 12 & 5.31 & 207 & 91.59* \\
\hline & \multirow{2}{*}{ Middle } & Internal & 13 & 24.53 & 10 & 18.87 & 30 & $56.60 *$ \\
\hline & & External & 9 & 4.27 & 11 & 5.21 & 191 & $90.52 *$ \\
\hline & \multirow{2}{*}{ Last } & Internal & 15 & 28.85 & 7 & 13.46 & 30 & $57.69 *$ \\
\hline & & External & 5 & 7.14 & 10 & 4.76 & 185 & 88.10* \\
\hline \multirow{8}{*}{ 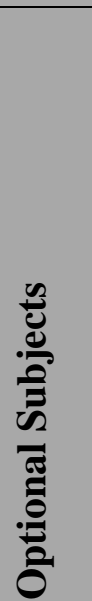 } & \multirow{2}{*}{ Language } & Internal & 6 & 18.75 & 7 & 21.88 & 19 & $59.43 *$ \\
\hline & & External & 4 & 2.72 & 7 & 4.76 & 136 & 92.52* \\
\hline & \multirow{2}{*}{ Arts } & Internal & 8 & 23.53 & 8 & 23.56 & 18 & 52.94* \\
\hline & & External & 2 & 2.27 & 2 & 2.27 & 84 & $95.45^{*}$ \\
\hline & \multirow{2}{*}{ Science } & Internal & 20 & 28.17 & 11 & 15.49 & 40 & $56.34 *$ \\
\hline & & External & 17 & 7.17 & 17 & 7.17 & 203 & 85.65* \\
\hline & \multirow{2}{*}{ Mathematics } & Internal & 10 & 27.03 & 6 & 16.22 & 21 & $56.76^{*}$ \\
\hline & & External & 7 & 4.00 & 7 & 4.00 & 161 & 92.00* \\
\hline
\end{tabular}

*indicates the level of emotional intelligence.

\section{Inference}

The above table inferred that the emotional intelligence and locus of control (internal and external) of student teachers in terms of birth orders and optional subjects studying in the college of Education is high. 
$H_{6}$ : There is no significant difference in emotional intelligence between the student teachers of internal and external locus of control in terms of birth order and optional subjects.

Table 6, The table shows that the difference between Student and Teachers of Internal and External Locus of Control in Emotional Intelligence in terms of Birth Order and Optional Subjects.

\begin{tabular}{|c|c|c|c|c|c|c|c|c|}
\hline \multirow{7}{*}{ 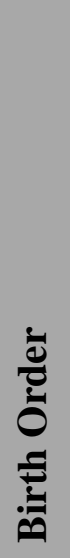 } & Category & $\begin{array}{l}\text { Locus of } \\
\text { Control }\end{array}$ & $\mathbf{N}$ & Mean & SD & $\begin{array}{l}\text { Calculated } \\
\text { ' } t \text { ' Value }\end{array}$ & $\begin{array}{l}\text { Table } \\
\text { Value }\end{array}$ & Remark \\
\hline & \multirow{2}{*}{ First } & Internal & 69 & 87.32 & 32.79 & \multirow{2}{*}{10.15} & \multirow{2}{*}{1.96} & \multirow{2}{*}{ S } \\
\hline & & External & 226 & 131.45 & 27.32 & & & \\
\hline & \multirow{2}{*}{ Middle } & Internal & 53 & 86.72 & 31.48 & \multirow{2}{*}{8.79} & \multirow{2}{*}{1.96} & \multirow{2}{*}{$S$} \\
\hline & & External & 211 & 128.55 & 28.90 & & & \\
\hline & \multirow{2}{*}{ Last } & Internal & 52 & 85.52 & 35.86 & \multirow{2}{*}{7.40} & \multirow{2}{*}{1.96} & \multirow{2}{*}{ S } \\
\hline & & External & 210 & 125.59 & 30.95 & & & \\
\hline \multirow{8}{*}{ 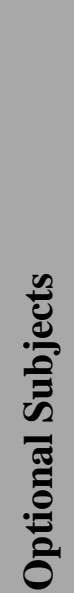 } & \multirow{2}{*}{ Language } & Internal & 32 & 90.41 & 31.95 & 6.57 & 1.96 & S \\
\hline & & External & 147 & 130.05 & 25.77 & & & \\
\hline & \multirow{2}{*}{ Arts } & Internal & 34 & 83.26 & 33.79 & 8.26 & 1.96 & $S$ \\
\hline & & External & 88 & 134.58 & 21.00 & & & \\
\hline & \multirow{2}{*}{ Science } & Internal & 71 & 84.97 & 34.12 & 8.86 & 1.96 & $S$ \\
\hline & & External & 237 & 125.68 & 33.40 & & & \\
\hline & \multirow{2}{*}{ Mathematics } & Internal & 37 & 87.38 & 33.05 & \multirow{2}{*}{7.10} & \multirow{2}{*}{1.96} & \multirow{2}{*}{$S$} \\
\hline & & External & 175 & 128.78 & 27.92 & & & \\
\hline
\end{tabular}

\section{$S=$ Significant at $5 \%$ level}

\section{Inference}

The above table inferred that the calculated 't' values of emotional intelligence and locus of control (internal and external) of student teachers in terms of birth orders and optional subjects studying in the college of Education is higher than the table value. It indicates that there is a significant difference between emotional intelligence and locus of control (internal and external) of student teachers studying in Chennai districts.

\section{FINDINGS AND DISCUSSION}

1. The Locus of Control of Student Teachers in Colleges of Education in Chennai is found to be predominantly External (78.81\%). Only $21.19 \%$ is found to be Internal. It is contrary to the assumption that it would be Internal (Table -1). 


\section{Emotional Intelligence - A Factor Influencing the Nature of Locus of Control of Student Teachers - An Analytical Study}

The Student Teachers being Graduates and Post Graduates are expected to be objective and scientific oriented in their thinking and dealings. As blooming teachers they would be setting realistic goals for future achievements. Therefore in all possibilities they should have developed Internal Locus of Control for achieving better performance in all their activities. Since their Locus of Control is External it may be interpreted that it may be due to the cultural impact of attributing all personal achievements to the guidance of gods and goddesses. Or the fullest state of their maturity in social and emotional domains may make them humble enough to attribute all their achievement to others.

2. The level of Emotional Intelligence of Student Teachers in Colleges of Education in Chennai is found to be high as assumed (Table -2).

The Social and Emotional characteristic constitute the Socio - Emotional factor of Emotional Intelligence. Quite a number of studies have shown that Emotional Intelligence is a dominant factor to cause higher level performance in individuals of different pursuits. As it is playing a crucial role in inter personal relationship, its importance can never be undermined for strengthening social coherence among the members of a society. The Student Teachers are undergoing training for the modification of behaviour in all the three important domains Cognitive, Affective, and Psycho - motor. Hence the Student Teachers were supposed to have developed Emotional Intelligence at a higher level because of the Environment available in colleges of Education.

3. The level of Emotional Intelligence of Student Teachers having Internal, External Locus of Control is found to be High (Table -3).

However the table 11.3 shows that $56.90 \%$ of Student Teachers having Internal Locus of Control fall under high Emotional Intelligence; where as $90.11 \%$ of the sample falls under the External category. Such a large difference in percentages of the sample of Internal and External Locus of Control under high category of Emotional Intelligence is confirmed by the differential analysis presented in Table-4. That is the Percentage difference is proved to be correct by the statistical difference in the means of Internals and Externals in Emotional Intelligence.

From this it may be inferred that Emotional Intelligence is capable of influencing both Internals and Externals, though its dominance is felt among the Externals greater than those of Internals. In other words it may be stated that Emotional Intelligence is acting as a strong causative factor for an individual being External in his / her Locus of Control.

4. Table-5 shows that irrespective of Birth Order and Optional Subjects the Student Teachers of Internal and External Locus of Control are found to be high in Emotional Intelligence. 
It is almost the same as in the case of Emotional Intelligence of the total sample. That is the sub samples formed of birth order and optional subjects do not seem to vary in the level of Emotional Intelligence of both Internals and Externals. In short it may be stated that the Birth Order and the Optional Subjects are not having any impact over the Internals and Externals in manifesting their Emotional Intelligence. Furthermore it is confirmed by the differential analysis. Table-6 reveals that the Externals irrespective of the Order of Birth and the Optional Subjects are more dominant in Emotional Intelligence then those of Internal Locus of Control. As in the case of total sample, the sub samples behave in the case of their Emotional Intelligence with Externals scoring more than the Internals.

\section{CONCLUSION}

The Researcher concludes that the Student Teachers with External Locus of Control are superior to Internals in their Emotional Intelligence. It is found to be the same in the case of all the sub samples. That is the status of Birth Order and the type of Optional Subjects is quite insignificant in altering the level of Emotional Intelligence in Externals and Internals. Therefore a series of in depth studies may be undertaken to verify the factors responsible for the Student Teachers to exhibit External Locus of Control more than that of the Internal.

\section{REFERENCES}

Arul Selvi. V (2006) "A study on personality types and academic achievement of higher secondary students of selected schools in Kancheepuram District. Unpublished thesis submitted to University of Madras, Chennai.

Best. J.W. (1988) Research in Education, New Delhi, Prentice Hall of India Pvt ltd.

Catherine. S. and Dr. I. Muthuchamy (2014) "Perceived Self-Efficacy of B.Ed. student Teachers in Relation to their Attitude towards Teaching". An international journal of education and Humanities, Volume: III, APH Publishing Corporation, New Delhi.

Erikson, R. V. and Roberts, A: H. (1971). Some Ego Functions Associated with Delay of Gratification in Male Delinquents. Journal of Consulting and Clinical Psychology, 36: 378-382,

Goleman, D. (1995) Emotional Intelligence, Bantam Book, New York. Gershaw, D.A. (1989).

Joshi, Renuka, (1989) "Creativity relation to personality locus of control in orientation in professional students”. M. B. Buch, fifth survey of educational research, Volume-I and II, NCERT (2000), New Delhi, p-9084.

Kalaiyarasi (2000) "An investigation of teacher effectiveness in relation to introversion and extroversion type of personality”. M.Phil thesis October 2000, Stella Matituna College of Education, Chennai. 
Kothari C.R., (1997) Research Methodology, methods and Techniques Willey eastern limited, New Delhi.

Kumari, Sasikala, (1991) “The effect of intelligence, achievement in biology and extraversion on the questioning of student IX pupils”. M. B. Buch, fifth survey of educational research, Volume-I and II, NCERT, New Delhi, p-6669.

Robert A. Baron (2006) Psychology, Prentice Hall of India Pvt. Ltd., New Delhi. 